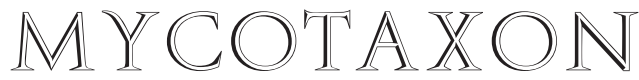

Volume 126, pp. 61-70

October-December 2013

\title{
Entocybe haastii from Watagans National Park, New South Wales, Australia
}

\author{
Sarah E. Bergemann ${ }^{1}$, David L. Largent ${ }^{2 *}$, \& Sandra E. Abell-Davis ${ }^{3}$ \\ ${ }^{1}$ Biology Department, Middle Tennessee State University, \\ PO Box 60, Murfreesboro TN 37132, United States \\ ${ }^{2}$ Biological Sciences, Humboldt State University, 1 Harpst St, Arcata CA 95521, United States \\ ${ }^{3}$ School of Marine and Tropical Biology, Australian Tropical Herbarium and Centre \\ for Tropical Environmental \& Sustainability Science, James Cook University, \\ PO Box 6811, Cairns QLD 4870 Australia
}

*CORRESPONDENCE TO: mrp@humboldt1.com

\begin{abstract}
AвSTRACT - Entocybe haastii comb. nov. ( Entoloma haastii) is distinguished by isodiametric minutely rounded pustulate-angular basidiospores, a dark blue black to nearly black pileus that lacks brown tones, dark blue grey lamellae, an appressed fibrillose blackish blue stipe, intracellular pigment in the pileipellis and inflated hyphae in the outer pileal trama, and the faintly parietal pigment on narrow pileal tramal hyphae.
\end{abstract}

KeY wORDs - Basidiomycota, Entolomataceae, new combination

\section{Introduction}

Entocybe T.J. Baroni et al. (Basidiomycota, Agaricales, Entolomataceae) was erected to accommodate a monophyletic group of species with the following set of morphological features: a slender tricholomatoid or mycenoid to collybioid habit, a relatively fragile, appressed fibrillose stipe, small, obscurely angular basidiospores with 6-10 facets (angles) in polar view and undulate-pustulate or rounded pustulate surface ornamentation overall, and a pileipellis subtended by inflated hyphae in the outer pileal trama (Baroni et al. 2011). An agaricoid fungus with this character set recently collected in Watagans National Park in central New South Wales was determined to be Entoloma haastii, a new report for mainland Australia. Herein, we recombine E. haastii in Entocybe.

\section{Materials \& methods}

\section{Macromorphological and micromorphological features}

Techniques and equipment for collecting and describing basidiomata in the field, GPS coordinates, microscopy of dried collection including how basidiospores were 
TABLE 1. Collections used in the phylogenetic analyses.

\begin{tabular}{|c|c|c|c|c|}
\hline \multirow[b]{2}{*}{ Species from GenBank } & \multirow{2}{*}{$\begin{array}{l}\text { COLLECTION } \\
\text { IDENTIFIER }\end{array}$} & \multicolumn{3}{|c|}{ GENBANK ACCESSION NUMBERS } \\
\hline & & $\mathrm{mtSSU}$ & LSU & RPB2 \\
\hline \multirow[t]{3}{*}{ Calliderma sp. } & DLL 10025 & JQ793648 & JQ793642 & - \\
\hline & DLL 10054 & - & JQ793649 & - \\
\hline & DLL 10088 & JQ793643 & JQ793650 & JQ793657 \\
\hline Clitocybe dealbata & HC95cp & AF357138 & AF223175 & DQ825407 \\
\hline Clitopilopsis hirneola & $8490 \mathrm{TJB}$ & GU384587 & GU384611 & GU384646 \\
\hline Cl. hirneola [Clitopilus hirneolus] & 263 & GQ289352 & GQ289211 & GQ289278 \\
\hline Clitopilus cystidiatus & 26 & GQ289287 & GQ289147 & GQ289220 \\
\hline \multirow[t]{2}{*}{ C. prunulus } & $8229 \mathrm{TJB}$ & - & GU384615 & GU384650 \\
\hline & 9663ТJB & GU384586 & GU384614 & GU384648 \\
\hline C. "cinerascens" & $8024 \mathrm{TJB}$ & GU384585 & GU384613 & GU384647 \\
\hline \multirow[t]{2}{*}{ Entocybe haastii } & DLL 9868 & JQ793644 & JQ793651 & JQ793658 \\
\hline & DLL 10087 & JQ793645 & JQ793652 & JQ793659 \\
\hline Entc. haastii [Entoloma haastii] & 126 & GQ289307 & GQ289167 & GQ289238 \\
\hline \multirow[t]{2}{*}{ Entc. nitida $[$ E. nitidum $]$} & $7526 \mathrm{TJB}$ & GU384602 & GU384626 & GU384655 \\
\hline & $\mathrm{s}$ & GQ289315 & - & GQ289246 \\
\hline Entc. nitida $[$ E. alcedicolor $]$ & 210 & GQ289292 & GQ289152 & GQ289224 \\
\hline \multirow[t]{2}{*}{ Entc. trachyospora $[$ E. trachyosporum $]$} & 414 & GQ289339 & GQ289199 & - \\
\hline & 405 & GQ289338 & GQ289198 & - \\
\hline Entc. trachyospora $[R$. trachyospora $]$ & $5856 \mathrm{TJB}$ & GU384605 & GU384629 & GU384658 \\
\hline \multirow{2}{*}{ Entc. turbida [E. turbidum] } & 27 & GQ289341 & GQ289201 & GQ289269 \\
\hline & $6949 \mathrm{TJB}$ & GQ289341 & GQ289201 & GQ289269 \\
\hline Entc. vinacea $[$ E. vinaceum $]$ & $8870 \mathrm{TJB}$ & GU384598 & GU384631 & GU384651 \\
\hline E. bloxamii & 219 & GQ289294 & GQ289154 & GQ289226 \\
\hline E. caesiolamellatum $[$ E. bloxamii $]$ & $6117 \mathrm{TJB}$ & - & AF261289 & - \\
\hline \multirow[t]{2}{*}{ E. coeruleogracilis [E. haastii] } & 216 & GQ289308 & GQ289168 & GQ289239 \\
\hline & 217 & GQ289309 & GQ289169 & GQ289240 \\
\hline E. cretaceum & 213 & GQ289302 & GQ289162 & GQ289233 \\
\hline E. gelatinosum & 212 & GQ289305 & GQ289165 & GQ289236 \\
\hline E. griseolazulinum & i11 & GQ289306 & GQ289166 & GQ289237 \\
\hline E. indigoticoumbrinum & 83 & GQ289318 & GQ289178 & GQ289249 \\
\hline E. kermandii & 222 & GQ289313 & GQ289173 & GQ289244 \\
\hline E. perbloxamii & 71 & GQ289318 & GQ289178 & GQ289249 \\
\hline E. prunuloides & 40 & GQ289324 & GQ289184 & GQ289255 \\
\hline \multirow[t]{3}{*}{ Entoloma sp. } & DLL 10217 & JQ793646 & JQ793653 & JQ793660 \\
\hline & BY21 & - & AF261309 & - \\
\hline & DLL 10055 & - & JQ793655 & JQ793662 \\
\hline Lepista ovispora & 442 & GQ289347 & GQ289207 & GQ289274 \\
\hline Rhodocybe sp. [Clitopilus sp.] & 211 & GQ289353 & GQ289212 & GQ289279 \\
\hline R. aureicystidiata & PBM1902 & - & AY380407 & AY337412 \\
\hline R. caelata $[$ C. caelatus $]$ & 6995ТJB & GU384600 & GU384625 & GU384652 \\
\hline R. fallax & CBS129.63 & AF357083 & AF223166 & EF421051 \\
\hline \multirow[t]{2}{*}{ R. fallax [C. fallax $]$} & 262 & GQ289349 & GQ289210 & GQ289275 \\
\hline & 37 & GQ289350 & GQ289276 & GQ289276 \\
\hline R. mundula & 7599TJB & - & AY700182 & DQ474128 \\
\hline \multirow[t]{2}{*}{ R. nitellina [C. nitellinus] } & 265 & GQ289354 & GQ289214 & GQ289281 \\
\hline & 400 & GQ289355 & GQ289215 & GQ289282 \\
\hline R. pallidogrisea [C. pallidogriseus] & 118 & GQ289356 & GQ289216 & GQ289283 \\
\hline R. popinalis [C. popinalis] & 260 & - & GQ289213 & GQ289280 \\
\hline R. popinalis & $6378 \mathrm{TJB}$ & GU384601 & AF261285 & GU384654 \\
\hline R. pruinosostipitata & MCA1492 & GU384608 & GU384627 & GU384653 \\
\hline R. pseudopiperita [C. pseudopiperitus] & 162 & GQ289357 & GQ289217 & GQ289284 \\
\hline R. spongiosa & MCA2129 & GU384604 & GU384628 & GU384657 \\
\hline Tricholoma vaccinum & 446 & GQ289358 & GQ289219 & GQ289286 \\
\hline T. viridiolivaceum & PBM3093 & - & JF706317 & JF706319 \\
\hline
\end{tabular}

New sequences generated for this study are shown in bold. Square bracketed annotations indicate species names applied in GenBank that differ from those in the phylogram (FIG. 1). 


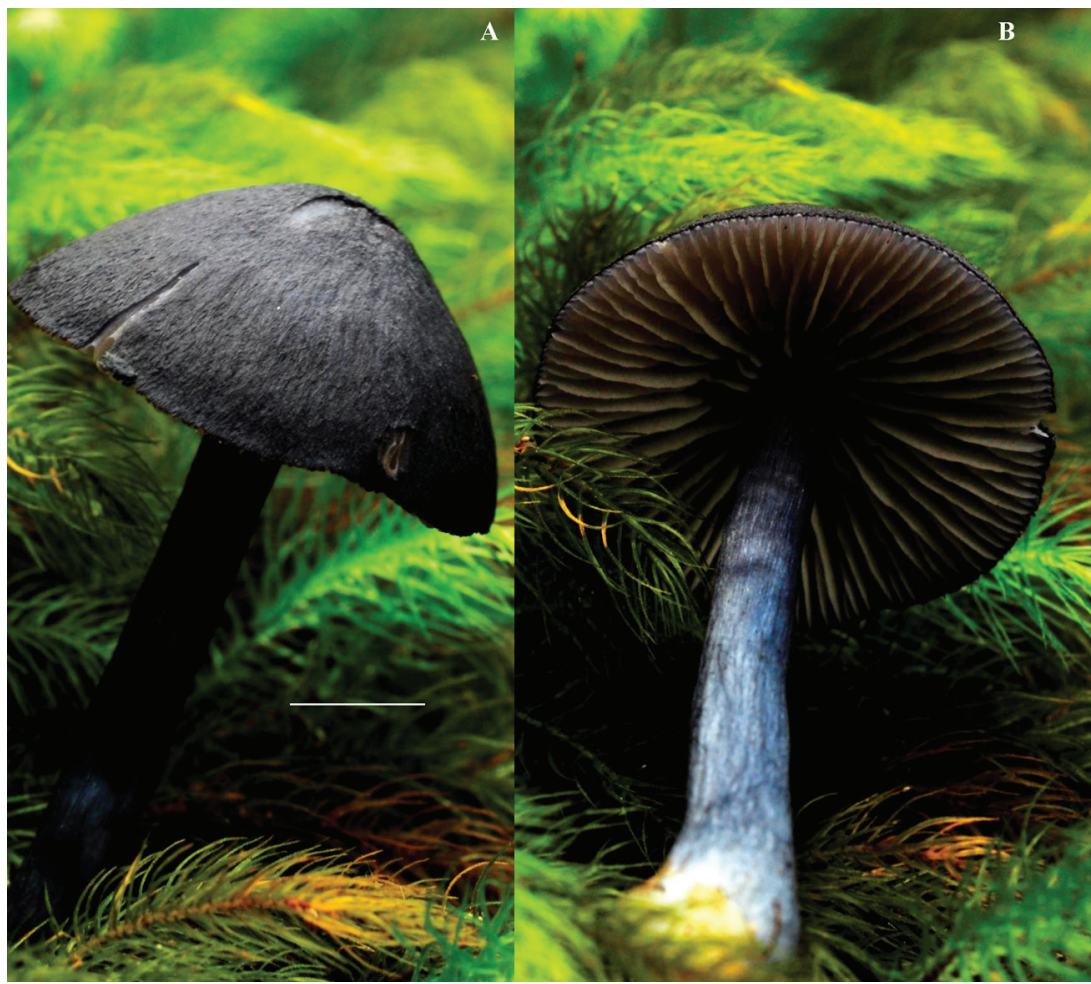

Plate 1. Entocybe haastii \{DLL 10087\}. A: Densely appressed-fibrillose pileus surface; B: Dark bluish-grey lamellae and stipe apex. Bar $(\mathrm{A}, \mathrm{B})=5 \mathrm{~mm}$.

measured, and digital microphotographs have been described in Largent et al. (2011a,b), while techniques for describing, coding, naming colors from Kornerup \& Wanscher (1978) and factors determined from mathematical analyses in the descriptions are covered in Largent et al. (2013). Generic abbreviations used are: E. = Entoloma; Entc. $=$ Entocybe.

The holotype collection and one additional collection are deposited in The Plant Pathology Herbarium, Orange Agricultural Institute (DAR). The herbarium acronym is from Thiers (2012).

\section{DNA sequences}

Sequences were obtained for three loci (mtSSU, LSU, RPB2) for two E. haastii collections from Australia (TABLE 1). The extraction and Polymerase Chain Amplification (PCR) protocols for the mitochondrial small subunit of the ribosomal DNA (mtSSU), variable domains (D1, D2) of the nuclear large subunit (LSU) and the second largest subunit of the RNA polymerase gene (RPB2) follow Largent et al. (2011b). The primers rpb2-i6f and rpb2-i7r or rpb2-EntF2 and rpb2-EntR4 were used to amplify the RPB2 (Co-David et al. 2009, Largent et al. 2013). Sequences were generated on an Applied 
Biosystems 3130xl Genetic Analyzer at Middle Tennessee State University using the sequencing protocols outlined in Largent et al. (2011b).

Sequences were assembled and edited using Sequencher ver. 4.2.2 (Gene Codes Corporation, Ann Arbor, MI) and multiple sequence alignments were generated using MAFFT version 7.1 (Katoh \& Standley 2013) and adjusted manually using Se-Al ver. 2.0a11 Carbon (Rambaut 2002) after exclusion of introns from the RPB2 alignment. The combined mtSSU, LSU and RPB2 sequences were aligned with closely related sequences from GenBank within the Prunuloides clade, representatives of the basal RhodocybeClitopilus clade, and appropriate outgroups (Matheny \& Baroni 2011) (TABLE 1). The alignment lengths were 1909 bp (mtSSU), 1472 bp (LSU), and 972 bp (RPB2).

The sequence alignment was analyzed using a Maximum Likelihood (ML) search GTRGAMMA model using RAxML-HPC v. 7.2.8 ALPHA (Stamatakis 2006). The dataset was partitioned using 4 partitions: RPB2 (across each codon position), mtSSU and LSU. Bootstrap proportions were estimated based on 1000 rapid ML replicates and 1000 bootstrap replicates (Stamatikas et al. 2008).

\section{Results}

The best likelihood tree in RaxML showed that species identified as Entocybe (Baroni et al. 2011) formed a well-supported clade (BS =97, Figure 1) and lends further support for the generic concept as defined by Baroni et al. (2011). Additional comments on Entc. haastii are provided in the Comments section.

\section{Taxonomy}

Entocybe haastii (G. Stev.) Largent, comb. nov.

Plates 1-3

MycoBank MB 804015

Entoloma haastii G. Stev., Kew Bull. 16(2): 229 (1962).

HaвIT mycenoid but with a broad stipe base. PILEUs 24-33 mm broad, 10-11 $\mathrm{mm}$ high, umbo obscurely broad, opaque, not hygrophanous, not translucentstriate, dull, moist but not sticky, conic- or convex-campanulate, densely appressed- or matted-fibrillose, rivulose, dark blackish blue (19F3 or 19F3-4) to nearly black, lacking any brown color, becoming silky or satiny appressed fibrillose with maturity; margin decurved, entire becoming slightly eroded; context $0.75-2.0 \mathrm{~mm}$ thick above the stipe, \pm violaceous. ODor mild or faintly fragrant. TASTE mild, at times suggestively sweet. LAMELLAE 11-15 mm long, 5.5-11.0 mm broad, narrowly adnate or adnate, close, at first dark bluish grey (19E-F2-3) with basidiospore maturity pale orange (6A3) then orange grey (6B2); margin smooth and concolorous. STIPE 40-65 3-5 (apex) - 4-10 mm (middle) - 6-12 (base) $\mathrm{mm}$, clavate, shiny and glossy, appressed-fibrillose, blackish blue but somewhat lighter than the pileus (19E5 or 20F6), white or yellowish white at the base, hollow and splits longitudinally with ease; context cartilaginous, white at least at the base; basal tomentum absent. BRUISING REACTIONS none. 


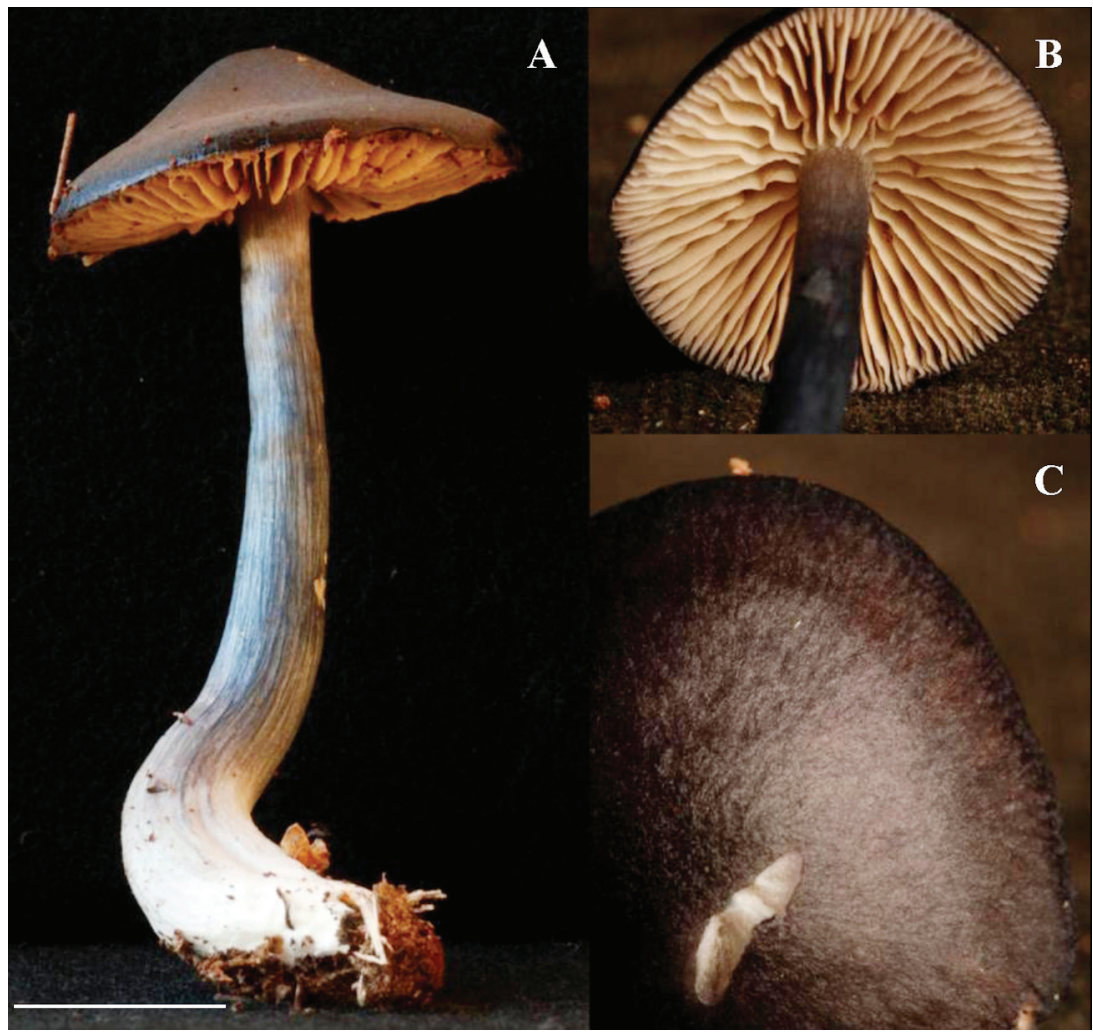

Plate 2. Entocybe haastii \{DLL 9868 A, B; DLL 10087 C\}. A: Stature; B: Mature lamellae; C: Mature pileal surface. Bar for $A, B=15 \mathrm{~mm} ; C=10 \mathrm{~mm}$.

BASIDIOSPORES in squashed mounts of lamellae in 3\% $\mathrm{KOH}$ often collapsed and thin-walled, some distinctly angular and some indistinctly to faintly rounded pustulate, in mounts from stipe surface decidedly rounded pustulate with 6 or more facets, in profile view isodiametric to subisodiametric, rarely heterodiametric, in polar view isodiametric 6.4-9.5(-10.2) $\times 5.5-7.9(-9.0) \mu \mathrm{m}$ $(x=7.7 \pm 0.7 \times 6.9 \pm 0.6 \mu \mathrm{m} ; \mathrm{E}=0.96-1.31, \mathrm{Q}=1.11 \pm 0.07$ (isodiametric); $\mathrm{n}=90 / 2)$. BAsIDIA cylindro-clavate, hardly tapered, $26.2-39.8 \times 7.7-11.7 \mu \mathrm{m}$ $(x=32.1 \pm 3.8 \times 9.5 \pm 1.0 \mu \mathrm{m} ; \mathrm{E}=2.51-4.42, \mathrm{Q}=3.41 \pm 0.48 ; \mathrm{n}=26 / 2)$; 2 - or 4-sterigmate. Hymenial Cystidia absent. LAMELLAR TRAMAL HYPHAE subparallel, moderately short and broad, 48.2-131.3 × 7-30.2 $\mu \mathrm{m}$. PiLEIPELLIS mostly a multi-layered cutis with a few semi-erect terminal cells, subtended by inflated cells of the pileal trama. Pileocystidia (terminal cells) cylindric to narrowly obclavate, $54.1-81.1 \times 2.5-7.8 \mu \mathrm{m}(\mathrm{n}=7 / 1)$. Pileal tramal HYPHAE beneath the pileipellis, short, broad and inflated, $47-129 \times 8-22 \mu \mathrm{m}$ 
enlarging up to $188 \mu \mathrm{m}$ long and $33 \mu \mathrm{m}$ wide near the hymenium ( $\mathrm{n}=14 / 2)$. STIPITIPELLIS a cutis. CAULOCYSTIDIA and HYMENIAL CLUSTERS absent. OLEIFEROUS HYPHAE rare to scattered in the pileal trama. LipoId GLOBULES absent. Brilliant granules absent. Pigments cytoplasmic, brownish blue, soluble in $3 \% \mathrm{KOH}$ in pileipellis and inflated hyphae of outer pileal trama; faintly parietal or possibly encrusted on the narrow hyphae of the pileal trama. Clamp CONNECTIONs present on hyphae of all tissues.

ECOLOGY and DISTRIBUTION - solitary in soil among leaf litter or in mosses on a rock, warm gallery rainforest, Watagans National Park, New South Wales.

Collections examined - AUSTRALIA. New South Wales, Central Hunter District, the Watagans National Park, Boardinghouse Dam Track, 32 $59^{\prime} 58.6^{\prime \prime} \mathrm{S} 151^{\circ} 24^{\prime} 15.5^{\prime \prime} \mathrm{E}, 13$

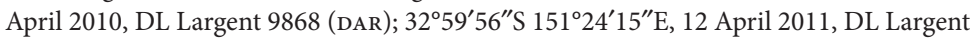
10087 (DAR).

Comments - Entocybe haastii from New South Wales lacks the brown color in the pileus reported for this species from Tasmania and New Zealand (Noordeloos \& Gates 2012). The lamellae from Tasmania are whitish while those from Australia and New Zealand are bluish-gray (Horak 2008, Noordeloos \& Gates 2012). This variability suggests that fine color distinctions are not diagnostic for Entc. haastii.

Similar to Entc. haastii, both Entc. nitida (Quel.) T.J. Baroni et al. (三Entoloma nitidum Quél.) from Europe and Entoloma alcedicolor Arnolds \& Noordel. from Holland have small isodiametric basidiospores and abundant clamp connections and lack cheilocystidia (Noordeloos 2004).

Entocybe nitida is distinguished from Entc. haastii by a glabrous or radially fibrillose pileus, white $30-100 \mathrm{~mm}$ long immature lamellae, $\leq 100 \mathrm{~mm}$ long cylindrical stipe, slightly farinaceous or raphanoid odor, and shorter and broader tramal cells subtending the pileipellis (Noordeloos 1981, 1992, 2004). Although Noordeloos (1992) identified basidiomata from Germany with bluish lamellae as Entc. nitidum, identification remains speculative as no collection was retained.

Entoloma alcedicolor differs from Entc. haastii by its steel blue pileus and stipe, garlic odor, squamulose pileus center, and trichodermial pileipellis on the center of the pileus.

Entoloma gracilior Noordel. \& G.M. Gates from Tasmania, which shares with Entc. haastii black pilei, lilac grey lamellae, a dark blue stipe as well as a similar pileipellis and basidiospores, differs in its more mycenoid stature and more slender (2-4 $\mathrm{mm}$ across the apex) equal stipe, a weakly hygrophanous smooth pileus with a translucent-striate margin, and heterodiametric basidiospores (Noordeloos \& Gates 2012).

Entoloma coeruleogracilis G.M. Gates \& Noordel., also from Tasmania, is distinguished by its sky blue stipe and pileus with a violet hue and the 1-3 $\mathrm{mm}$ broad cylindrical stipe. 


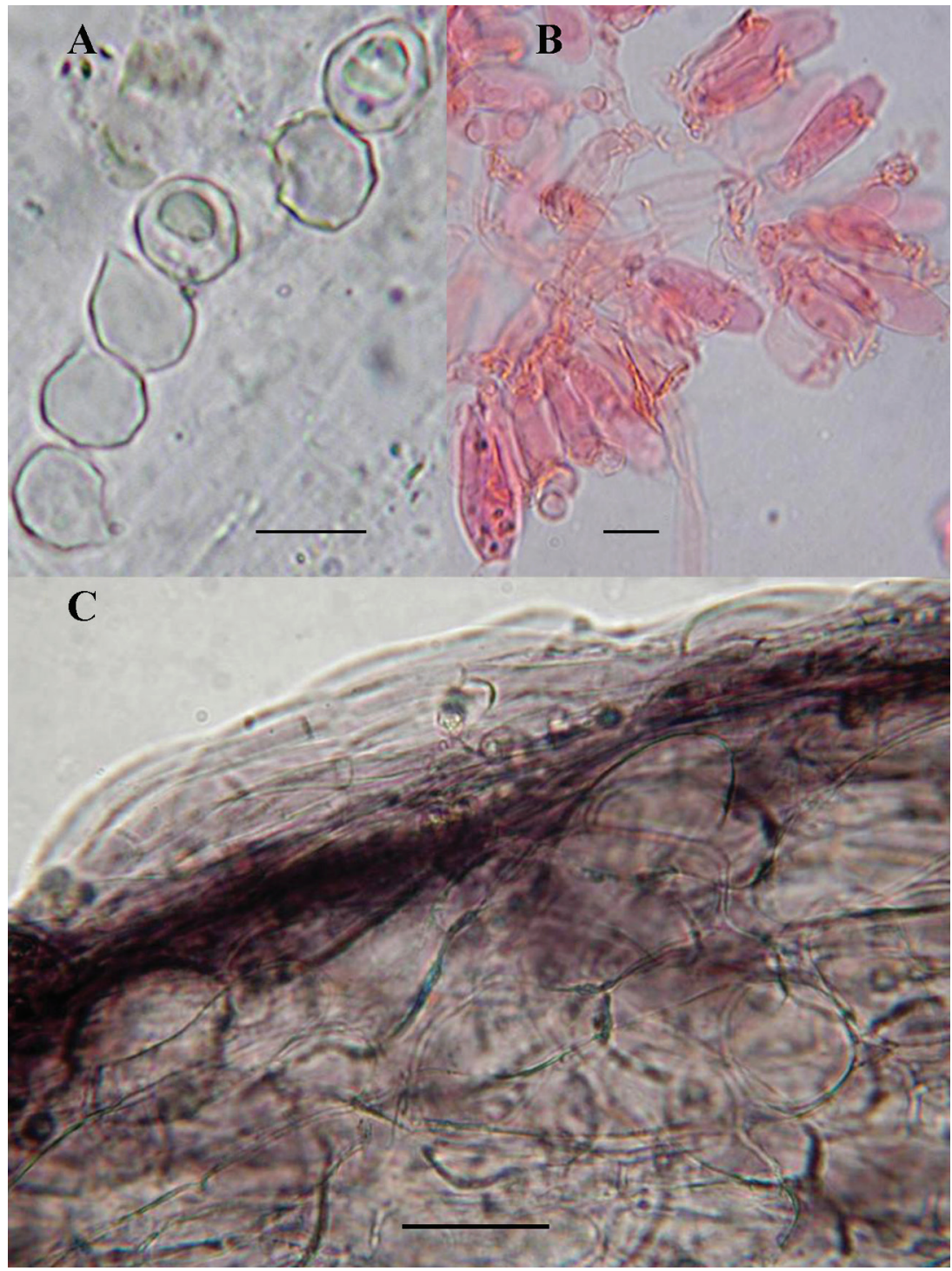

Plate 3. Entocybe haastii \{DLL 10087\}. A: Basidiospores from stipe surface; B: Basidia and basidioles; C: Pileipellis and subtending inflated cells in pileal trama. Bars $A=7.0 \mu \mathrm{m} ; \mathrm{B}=10 \mu \mathrm{m}$; $\mathrm{C}=22 \mu \mathrm{m}$.

Our phylogenetic analysis (FIG. 1) clearly supports (BS = 97) Entc. haastii within Entocybe as described by Baroni et al. (2011). Entocybe haastii, E. coeruleogracilis, Entc. nitida, and E. alcedicolor segregate as a sub-clade with 
moderate support $(B S=77)$. Noordeloos \& Gates $(2012)$ classify these taxa in Entoloma sect. Nitida (Romagn.) Noordel. based on a number of morphological features.

\section{Acknowledgments}

Fieldwork in Australia was supported by the Largent family trust and we are particularly grateful for the support of Pamela Largent. Fieldwork and logistical support were provided by the Australian Tropical Herbarium and the School of Marine and Tropical Biology, James Cook University. Comments by the two reviewers, Dr. Timothy J. Baroni and Dr. Terry W. Henkel, and Ms. Fernanda Karstedt and Nomenclature Editor Dr. Shaun Pennycook are also appreciated. We wish to thank Pam O'Sullivan as well as Skye Moore for their assistance in providing descriptions and sharing the location of collecting sites in New South Wales.

\section{Literature cited}

Baroni TJ, Hofstetter V, Largent DL, Vilgalys R. 2011. Entocybe is proposed as a new genus in the Entolomataceae (Agaricomycetes, Basidiomycota) based on morphological and molecular evidence. North American Fungi 6 (12): 1-19. http://dx.doi.org/10.2509/naf2011.006.012

Horak E. 2008. Agaricales of New Zealand. 1: Pluteaceae (Pluteus, Volvariella) Entolomataceae (Claudopus, Clitopilus, Entoloma, Pouzarella, Rhodocybe, Richoniella). Fungi of New Zealand Volume 5. Fungal Diversity Research Series 19: 1-305.

Katoh K, Standey D.M. 2013. MAFFT Multiple Sequence Alignment Software Version 7: Improvements in Performance and Usability. Molecular Biology and Evolution: 30: 772-780. http://dx.doi.org/10.1093/molbev/mst010

Largent DL, Abell-Davis SE, Cummings GA, Ryan KL, Bergemann SE. 2011a. Saxicolous species of Claudopus (Agaricales, Entolomataceae) from Australia. Mycotaxon 116: 253-264. http://dx.doi.org/10.5248/116.253

Largent DL, Bergemann SE, Cummings GA, Ryan KL, Abell-Davis SE, Moore S. 2011b. Pouzarella (Agaricales, Entolomataceae) from New South Wales (Barrington Tops National Park) and northeastern Queensland. Mycotaxon 117: 435-483. http://dx.doi.org/10.5248/117.435

Largent DL, Bergemann SE, Abell-Davis SE, Kluting KL, Cummings GA. 2013. Five Leptonia species from central New South Wales and Queensland, Australia. Mycotaxon 125:11- 35. http://dx.doi.org/10.5248/125.11

Noordeloos ME. 1981. Introduction to the taxonomy of the genus Entoloma sensu lato (Agaricales). Persoonia 11: 121-151.

Noordeloos ME. 1992. Entoloma s.l. in Fungi Europaei vol. 5. Ed. Candusso: Alassio, Italy.

Noordeloos ME. 2004. Entoloma s.l. in Fungi Europaei vol. 5A. Ed. Candusso: Alassio, Italy.

Noordeloos ME, Gates, GM. 2012. The Entolomataceae of Tasmania. Fungal Diversity Research Series 22: 1-399. http://dx.doi.org/10.1007/978-94-007-4679-4

Rambaut A, 2002. Sequence alignment editor. Version 2.0. Department of Zoology, University of Oxford, Oxford England.

FIGURE 1. Maximum likelihood tree (LSU+mtSSU+RPB2) showing the position of Entocybe haastii from Australia (AUS*) and Tasmania (TAS) relative to other Entocybe collections. Each sequence is labeled with the GenBank-listed isolate number. Branches with $>70 \%$ support from 1000 rapid bootstraps provide statistical support. Clitocybe dealbata, Lepista ovispora, Tricholoma vaccinum, and T. virdioviolaceum serve as outgroups. Three slanted lines denote truncated branches. 
0.08 substitutions/site

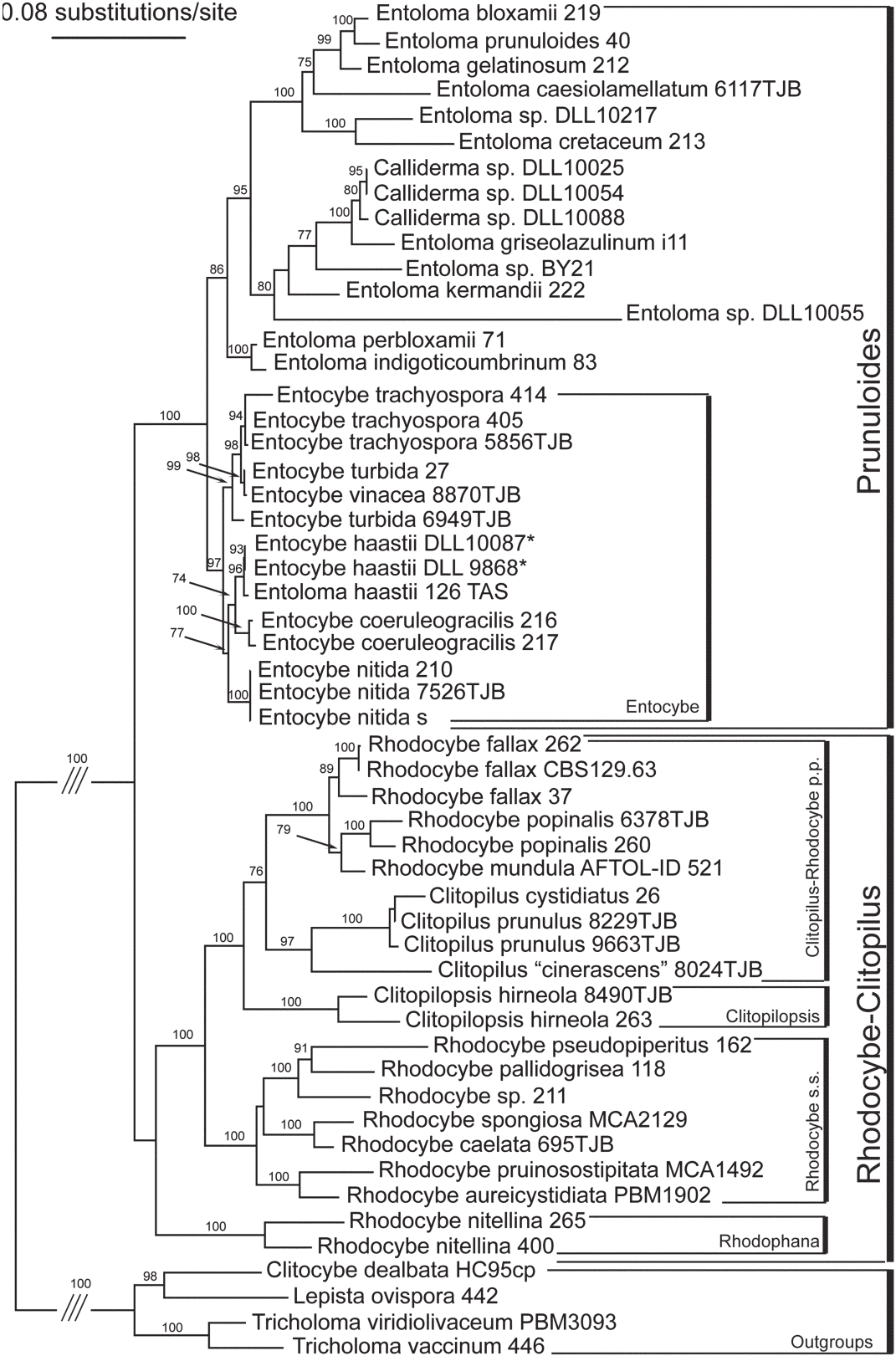


70 ... Bergemann, Largent \& Abell-Davis

Stamatakis A. 2006. RAxML-VI-HPC: maximum likelihood-based phylogenetic analyses with thousands of taxa and mixed models. Bioinformatics 22: 2688-2690.

http://dx.doi.org/10.1093/bioinformatics/btl446

Stamatakis A, Hoover P, Rougemont J. 2008. A rapid bootstrap algorithm for RAxML web servers. Systematic Biology 57: 758-771. http://dx.doi.org/10.1080/10635150802429642

Thiers B. 2012. Index Herbariorum: a global directory of public herbaria and associated staff. New York Botanical Garden’s Virtual Herbarium. http://sweetgum.nybg.org/ih/[accessed May 2012] 